\title{
H2AZ2 wt Allele
}

National Cancer Institute

\section{Source}

National Cancer Institute. H2AZ2 wt Allele. NCI Thesaurus. Code C162830.

Human H2AZ2 wild-type allele is located in the vicinity of 7p13 and is approximately $21 \mathrm{~kb}$ in length. This allele, which encodes histone H2A.V protein, plays a role in chromosome condensation. 